\title{
Variation of the baculum structure of the Palaearctic badger (Carnivora, Mustelidae, Meles)
}

\begin{abstract}
Alexei V. Abramov
ABSTRACT. The morphology of baculum (os penis) of the badger Meles meles from different parts of its Palaearctic range is examined. Three types of the bacular structure are distinguished. Morphological differences in the baculum between the European, continental Asian and Japanese populations support the previous splitting of the badger into three taxonomic forms. The status of these forms is here asserted to be of species level: the European badgerMeles meles (L., 1758), the Asian badgerM. leucurus (Hodgson, 1847), and the Japanese badger M. anakuma Temminck, 1844.
\end{abstract}

KEY WORDS. Meles, badgers, baculum, morphology, variability, taxonomy.

AlexeiV.Abramov[aav@aa2510.spb.edu],Zoological Institute, Russian Academy of Sciences, Universitetskaya nab. 1., Saint Petersburg 199034 Russia.

\section{Изменчивость строения бакулюма у палеарктических барсуков (Carnivora, Mustelidae, Meles)}

\begin{abstract}
А. В. Абрамов
РЕЗЮМЕ. Исследована морфология бакулюма (os penis) барсуков Meles meles из различных частей палеарктического ареала. Можно различить три типа бакулюма. Морфологические различия в структуре бакулюма между европейскими, континентальными азиатскими и японскими популяциями поддерживают прежнее разделение барсуков на три таксономические формы. В данной работе этим формам придается видовой статус: европейский барсукMeles meles (L., 1758), азиатский барсук M. leucurus (Hodgson, 1847) и японский барсук M. anakuma Temminck, 1844.
\end{abstract}

КЛЮЧЕВЫЕ СЛОВА. Meles, барсуки, бакулюм, морфология, изменчивость, таксономия.

\section{Introduction}

The baculum, or penis bone, of the European badger Meles meles (Linnaeus, 1758) was described in a number of works (Ognev, 1931; Didier, 1947b; Heptner et al., 1967; Lüps \& Wandeler, 1993; Baryshnikov \& Abramov, 1997), most of which either only described the bacular morphology, or used this structure for the age determination. Intraspecific variation in the structure of the badger baculum has been used for distinguishing age groups (Ahnlund, 1976; Graf \& Wandeler, 1982; Hancox, 1987). However, a geographic variation of the baculum structure of this widespread species has not been studied yet. The purposes of this paper are to describe a geographic variation of the baculum structure of the Palaearctic badger, and to comment on a taxonomic status of its different forms.

\section{Materials and methods}

We have examined the collections of the Zoological Institute, Russian Academy of Sciences (Saint Petersburg, Russia, ZIN), the Institute of Animal Systematics and Ecology, the Siberian Branch of Russian Academy of Sciences (Novosibirsk, Russia), the Kitakyushu Museum and the Institute of Natural History (Kitakyushu, Japan, KM), the Institute of Zoology, Uzbekistan Academy of Sciences (Tashkent, Uzbekistan) and the Craniological Laboratory of the CentralForest Natural State Reserve (Tver' Province, Russia). A total of 27 badger bacula from different localities has been analyzed with respect to their shape and measurements: nine from the north-western part of European Russia (Leningrad Province), one from the Tver' Province, one from the Western Kazakhstan, three from the South Urals (Chelyabinsk Province), five from the Uzbekistan, four from the Western Siberia (Novosibirsk Province), one from the Transbaikalia (Republic of Buryatia), one from the Northern Mongolia, and two from Japan (Kyushu Island). Localities of the Meles specimens examined in the present study are shown in Fig. 1. All measurements (in $\mathrm{mm}$ ) are given for adult specimens.

\section{Results}

All studied adult bacula falls into three well-differentiated types of bacular structure described below.

European type(Fig. 2A). The shaft is nearly straight, sometimes its distal end is slightly curved up. The proximal part of shaft is triangular in cross-section, its distal part is more flattened dorso-ventrally. The shaft is of equal (or nearly equal) width along its length. The shaft width near head is 3.9-4.3. The proximal end of the baculum base is slightly widened and strongly constricted laterally. The average height at base is 8.5 , average 


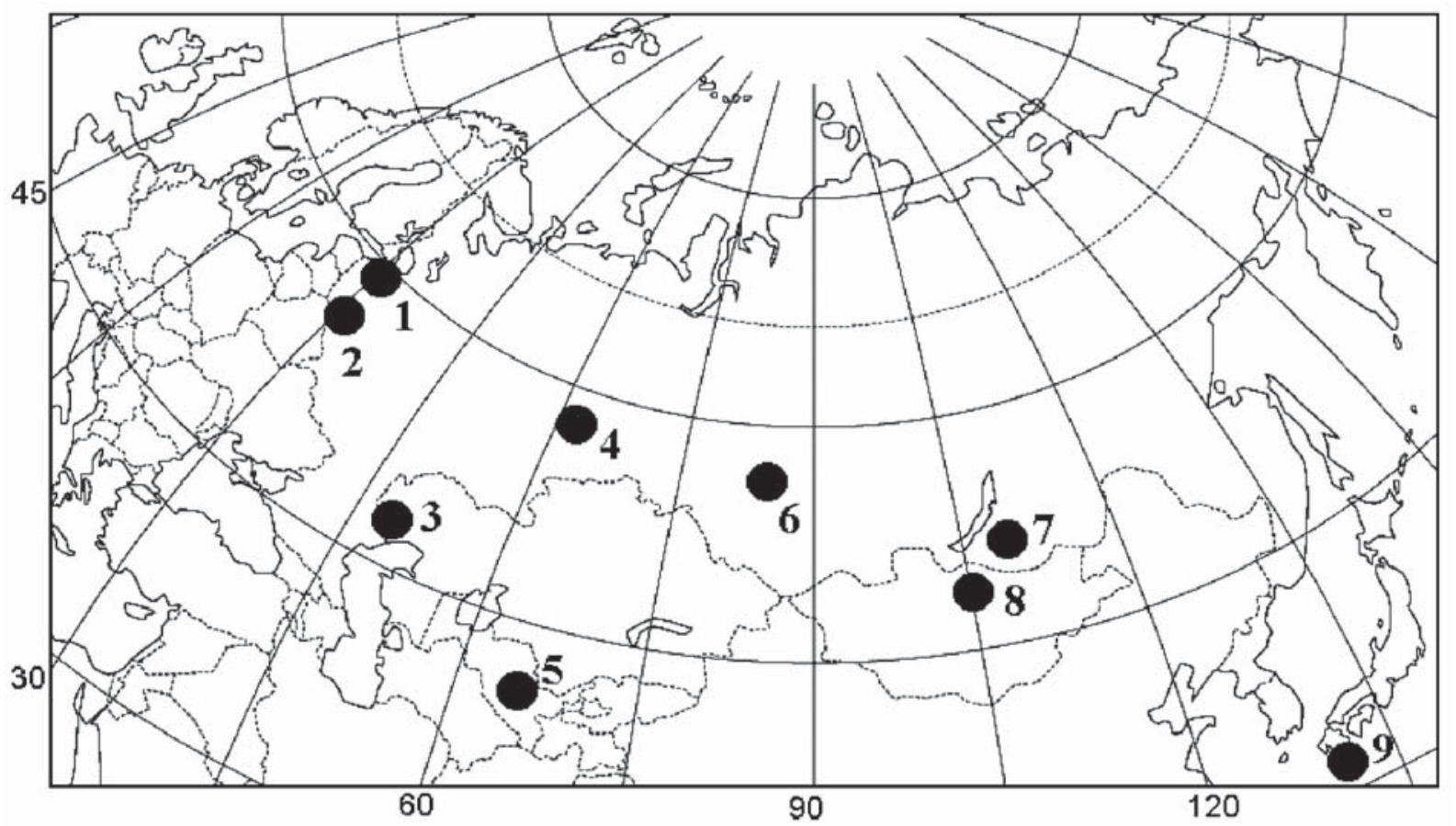

Figure 1. THE LOCALITIES OF THE MELES SPECIMENS EXAMINED: 1 - Leningrad Province, 2 — Tver' Province, 3 - Western Kazakhstan, 4 - Chelyabinsk Province, 5 - Uzbekistan, 6 - Novosibirsk Province, 7 - Republic of Buryatia, 8 - Northern Mongolia, 9 - Kyushu Island.
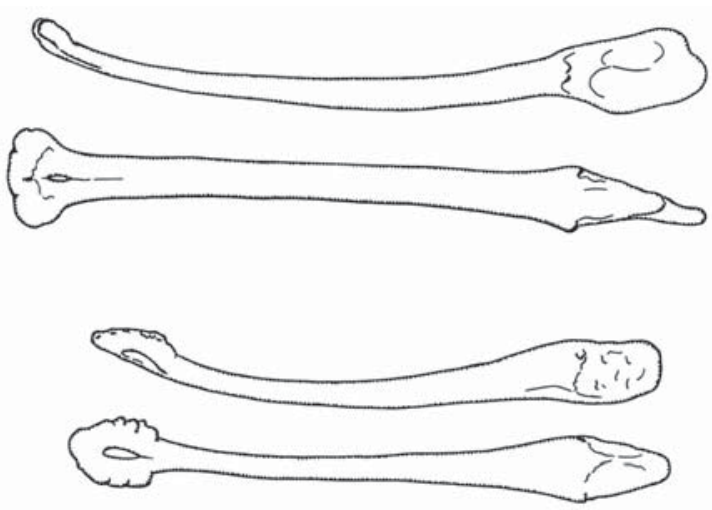

B

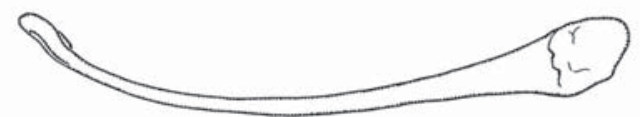

C

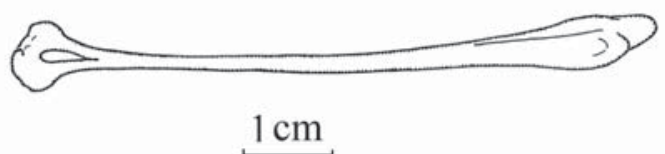

Figure 2. DIFFERENT TYPES OF BADGER BACULUM (in lateral view and dorsal view): A - European type (ZIN O.218, Leningrad Province, Russia); B - Asian type (ZIN O.35081, Buryatia, Russia); C - Japanese type (KM 931018-10, Kyushu Island, Japan). width at base is 7.2. Average length of adult bacula is $69.9(n=8)$ for specimens from the European part of Russia (according to Ognev (1931), the maximal length could be 74.0); $74.4(\mathrm{n}=10)$ for specimens from England (Hancox, 1987); $73.4(n=6)$ for specimens from Denmark (Hancox, 1987); and 77.8 ( $\mathrm{n}=6$ ) for specimens from France (Didier, 1947b). The baculum is relatively short $-53 \%$ of condylobasal length of the skull on average (for specimens from the European part of Russia).

The head of baculum is dorso-ventrally flattened to produce a spatular form. The bacular head is poorly separated from the shaft, with a small rounded central hole. The head surface is covered with small cavities. The head length is $6.4-7.3$, width is $8.2-10.3$.

The bacula of juvenile specimens have their distal end divided into two wide projections. With the age, these projections extend and merge, leaving a slotshaped hole in the middle part of the head. The baculum of the European badger achieves an adult shape, size and weight in 1.5-2 years; after this age, the bacular structure, including its length and weight, does not sufficiently changes (Ahnlund, 1976; Graf \& Wandeler, 1982; Hancox, 1987).

This type of the baculum has been found in the badgers from different parts of Europe: United Kingdom, Denmark (Hancox, 1987), France (Didier, 1947b), and the European part of Russia.

Asian type (Fig. 2B). The bacular shaft is strongly curved, circular in cross-section, but slightly squeezed laterally. The shaft tapering sharply to the distal end. The shaft width near the head is $2.7-3.3$. The base is very 
massive and large, not squeezed laterally as in the European type. The average height at base is 8.3 , the average width at base is 8.1 . Average length of the adult bacula is $68.3(n=11)$. It is $55 \%$ of condylobasal length of the skull.

The spatula-shaped head is well marked, large and massive, with a central elongated narrow hole. The head is elongated-oval or rounded. The head length is 8.311.1 , width is $7.4-8.7$.

The baculum of Asian juveniles, like in the European specimens, is divided into two wide projections at the distal end. These projections are merged in subadult specimens, forming a flat elongated head. Compared to the European subadults, the baculum base of Asian juveniles is more wide and swollen.

This type of the baculum has been found in the badgers from the Urals, Western Kazakhstan, Uzbekistan, Western Siberia, Transbaikalia, and Mongolia.

Japanese type (Fig. 2C). The two bacula examined of the Japanese specimens are sufficiently different from those of the continental badgers.

The baculum is relatively long (about $62 \%$ of condylobasal length of the skull). The shaft tapers to its distal end, bending mainly in the distal third. The shaft is very thin, triangular in cross-section at its base, and circular along its length. The shaft width near head is 2.5-2.8. The base is not so wide as in the Asian type, slightly rugose and squeezed laterally. The average height at base is 7.0, average width at base is 6.0. Average length of adult bacula is $69.3(\mathrm{n}=2)$.

The head is flat and triangular, slightly resembling a leaf of ginkgo. The adult specimen has a small central rounded hole, while the second (younger one) has an elongated, drop-shaped hole. The head surface is smooth. The length of head is 5.6-6.3, width is 7.7-9.6.

\section{Discussion}

The taxonomy of the Eurasian badgers is not clearly understood, although a geographic variation of cranial and external characters is known to be considerable. Most of the mammalogists consider $M$. meles as a single species of the genusMeles (Ellerman \& Morrison-Scott, 1951; Petrov, 1953; Heptner et al., 1967; Corbet, 1978; Wozencraft, 1993; Lynch, 1994). However, some authors indicated the remarkable differences between the European and Asian badgers in cranial characters and coloration. Some of them (Kastschenko, 1902; Satunin, 1914; Ognev, 1931) advocated the European and Asian forms to be distinct species, while others (Pocock, 1941; Petrov, 1953; Heptner et al., 1967) regarded these forms as subspecies (or groups of subspecies) only. The Japanese badger has usually been considered a separate subspecies being close to the Asian subspecies (or a group of subspecies) (Petrov, 1953; Heptner et al., 1967). Recently, Baryshnikov \& Potapova (1990) studied dental characters of the Palearctic badgers and supposed that there are two allopatric badger species, the European badger M. meles and the Asian badger $M$. anakuma. Despite no Japanese badger skulls were examined by these authors, they accepted the Japanese name anakuma as a valid name for the Asian (continental) badgers. Contrary to this opinion, Lynch (1994) considered Meles to be represented by two subspecies: continental M. m. meles and Japanese M. m. anakuma. By applying a multivariate approach, he examined an east-west clinal craniometric variation in the badgers across Eurasia and showed that solely the Japanese form is distinct by cranial characters. The recent data on the cytochrome $b$ sequence variation in $M$. meles from Japan and Eurasia also demonstrated that the sequence difference between the Japanese and continental populations is remarkably high (Kurose et al., 2001). The latter authors also revealed that the badgers from Siberia (Transbaikalia) and the European part of Russia (Leningrad Province) show a high difference in DNA sequences as well.

The results of a previous study of craniological and exterior characters of the Eurasian badgers (Abramov, 2001) also pointed the existence of the three well-separated forms (species) of Meles. The distinct morphological differences of the bacular structure described between the European, Asian (continental) and Japanese badgers (see above; Fig. 2) are also advocate the existence of three distinct species of Meles in the Palearctic.

The bacula of different species of Mustelidae are known to have distinctive morphological features of great taxonomic value. Even in closely related species the baculum morphology could be sufficiently different. Within the mustelids, an interspecific variation in the bacular structure has long been known and used for species diagnoses and taxonomy (Pocock, 1918, 1941; Chaine, 1926; Ognev, 1931; Didier, 1947a, b, 1948; Burt, 1960; Zyll de Jong, 1972; Baryshnikov \& Abramov, 1997; Abramov, 2000). The species-specific nature of bacular morphology allows to use bacular characters in taxonomy (e.g. Patterson \& Thaeler, 1982). An intraspecific variation of the adult bacular structure in all the mustelids is not wide and is clearly smaller than an interspecific variation (Baryshnikov \& Abramov, 1997).

It is worthy of note that some of other closely related, but distinct mustelid species, for example, the polecats (Mustela putorius L., 1758, M. eversmanii Lesson, 1827, and M. nigripes (Audubon et Bachman, 1851)) and the martens (Martes martes (L., 1758), M. zibellina (L., 1758), M. americana (Turton, 1806), andM. melampus (Wagner, 1841)) demonstrate differences in the bacular structure less prominent than described above for the Palaearctic badgers (Baryshnikov \& Abramov, 1997).

Thus, it is safe to conclude the Palaearctic genus Meles seems to include the three separate species: the European badger M. meles (L., 1758), the Asian badger M. leucurus (Hodgson, 1847), and the Japanese badger M. anakuma Temminck, 1844 . In order to further elucidate taxonomic relationships and ranges of these species of Meles, it is necessary to perform a detail morphological examination of more numerous samples from a larger number of localities across Eurasia. 
ACKNOWLEDGEMENTS. I thank Dr. M. Baba, Dr. R. Masuda, Dr. B. Abdunazarov, Dr. E. Zholnerovskaya, Dr. P. Korablev for access to the museum collections under their care. I am grateful to Dr. D. Logunov for preparing the drawings and checking the English of an earlier draft. I am very grateful to two anonymous reviewers for useful comments on earlier draft of the manuscript. This study was supported by Russian Foundation for Basic Research (grant No 02-04-48607).

\section{References}

Abramov A.V. 2000. A taxonomic review of the genus Mustela (Mammalia, Carnivora)//Zoosystematica Rossica. Vol.8 (for 1999). No.2. P.357-364.

Abramov A.V. 2001. [Notes on the taxonomy of the Siberian badgers (Mustelidae: Meles)] // Trudy Zoologicheskogo Instituta RAN. Vol.288. P.221-233 [in Russian, with English summary].

Ahnlund H. 1976. Age determination in the European badger, Meles meles L. // Zeitschrift für Säugetierkunde. Bd.41. Hf.1. P.119-125.

Baryshnikov G.F. \& Abramov A.V. 1997. [Structure of baculum (os penis) in Mustelidae (Mammalia, Carnivora), Communication 1] // Zoologicheskii Zhurnal. Vol.76. No.12. P.1399-1410 [in Russian, with English summary].

Baryshnikov G.F. \& Potapova O.R. 1990. [Variability of the dental system in badgers (Meles, Carnivora) of the USSR fauna] // Zoologicheskii Zhurnal. Vol.69. No.9. P.84-97 [in Russian, with English summary].

Burt W.H. 1960. Bacula of North American mammals // Miscellaneous Publications of the Museum of Zoology, University of Michigan. No.113. P.1-76.

Chaine J. 1926. L'os penien: étude descriptive et comparative // Actes de la Société Linnéene de Bordeaux. Vol.78. P.1195.

Corbet G.B. 1978. The mammals of the Palaearctic Region: a taxonomic review. London and Ithaca: Cornell University Press. 314 p.

Didier R. 1947a. Etude systematique de l'os penien des mammiferes // Mammalia. T.11. No.1-2. P.30-43.

Didier R. 1947b. Etude systematique de l'os penien des mammiferes // Mammalia. T.11. No.4. P.139-152.

Didier R. 1948. Etude systematique de l'os penien des mammiferes // Mammalia. T.12. No.3. P.67-93.

Ellerman J.R. \& Morrison-Scott T.C.S. 1951. Checklist of Palaearctic and Indian mammals (1758 to 1946). London: Trustees of British Museum (Natural History). 810 p.

Graf M. \& Wandeler A.I. 1982. Altersbestimmung bei Dachsen (Meles meles L.) // Revue Suisse de Zoologie. Vol.89. Fasc.4. S.1017-1024.
Hancox M. 1987. Baculum use in age determination in Eurasian badger // Mammalia. Vol.51. No.4. P.622-625.

Heptner V.G., Naumov N.P., Yurgenson P.B., Sludsky A.A., Chirkova A.F. \& Bannikov A.G. 1967. [Mammals of the Soviet Union. Vol.2. Part 1. Sea cows and carnivores]. Moskva: Vysshaya Shkola. 1004 p. [in Russian].

Kastschenko N.F. 1902. [About sandy badger (Meles arenarius Satunin) and about the Siberian races of badger] // Ezhegodnik Zoologicheskogo Muzeya Imperatorskoi Akademii Nauk. Vol.6 (for 1901). No.4. P.609-613. [in Russian].

Kurose N., Kaneko Y., Abramov A.V., Siriaroonrat B. \& Masuda R. 2001. Low genetic diversity in Japanese populations of the Eurasian badger Meles meles (Mustelidae, Carnivora) revealed by mitochondrial cytochrome $b$ gene sequences // Zoological Science. Vol.18. P.1145-1151.

Lüps P. \& Wandeler A.I. 1993. Meles meles (Linnaeus, 1758) - Dachs // Niethammer J.\& Krapp F. (eds.). Handbuch der Säugetiere Europas. Band 5. Teil 2. Wiesbaden: AULA-Verlag. S.855-906.

Lynch J.M. 1994. Morphometric variation in the badger (Meles meles): clinal variation in cranial size and shape across Eurasia // Small Carnivore Conservation. No.10. P.6-7.

Ognev S.I. 1931. [The Mammals of the Eastern Europe and Northern Asia]. Vol.2. Moskva-Leningrad: Gosizdat. 776 p. [in Russian].

Patterson B.D. \& Thaeler C.S., Jr. 1982. The mammalian baculum: hypotheses on the nature of bacular variability // Journal of Mammalogy. Vol.63. No.1. P.1-15.

Petrov V.V. 1953. [The data on the intraspecific variability of badgers (genus Meles)] // Uchenye Zapiski Leningradskogo Pedagogicheskogo Instituta. Vol.7. P.149-205 [in Russian].

Pocock R.I. 1918. The baculum or os penis of some genera of Mustelidae // Annals and Magazine of Natural History. Vol.1. No.4. P.307-312.

Pocock R.I. 1941. The fauna of British India, including Ceylon and Burma. Mammalia. Vol.2. London: Taylor and Francis, Ltd. 503 p.

Satunin K.A. 1914. [Key to mammals of the Russian Empire]. Vol.1. Tiflis: Tipografiya Kantselyarii Namestnika. 184 p. [in Russian].

Wozencraft W.C. 1993. Order Carnivora // Wilson D.E. \& Reeder D.M. (eds.). Mammal Species of the World: a Taxonomicand Geographic Reference, 2nd ed. Washington and London: Smithsonian Institution Press. P.279-348.

Zyll de Jong C.G., van. 1972. A systematic review of the Nearctic and Neotropical river otters (genus Lutra, Mustelidae, Carnivora) // Life Sciences Contributions, Royal Ontario Museum. Vol.80. P.1-104. 